\title{
Näkymätön vähemmistö: karjalankielisten karjalaisten nykytila Suomessa
}

\author{
Sarhimaa, Anneli 2017: Vaietut ja vaiennetut: Karjalankieliset karjalaiset \\ Suomessa.
}

Helsinki: SKS. 297 sivua.

\section{Eila Stepanova}

I Karjalahan on vaan suomen murre!" on väite, jonka kuulen jatkuvasti, ja kerta toisensa

Wälkeen joudun väittämään, että kieleni ja kulttuurini on itsenäinen ja omalaatuinen vaikkakin suomen lähisukulainen. Samaan ovat törmänneet monet muut Suomessa asuvat karjalaiset, kuten ilmenee Anneli Sarhimaan tutkimuksessa.

Karjalan kieltä on puhuttu Suomessa niin kauan kuin suomeakin, eli karjalankieliset muodostavat Suomessa autoktonisen eli kotoperäisen kieli- ja kulttuurivähemmistön. Tästä huolimatta heidän oikeutensa omaan kieleen ja kulttuuriin on poljettu ainakin vuoteen 2009 saakka, jolloin karjalan kieli lisättiin niiden kielten joukkoon, joiden tilanteesta Suomi raportoi Euroopan neuvostolle. Kuitenkin karjala on näkymätön lainsäädännössä. Sitä ei edelleenkään mainita Suomen perustuslaissa muiden kotoperäisten kielten joukossa, eikä karjalalle ole säädetty omaa kielilakiaan. Tietoisesti harjoitetusta poliittisesta syrjinnästä huolimatta karjalan kieli elää Suomessa edelleen, vaikka kieli on tällä hetkellä erittäin uhanalainen, toteaa Anneli Sarhimaa (s. 187-197).

\section{Selkeärakenteinen ja kokonaisvaltainen tietopaketti}

Anneli Sarhimaan kirja Vaietut ja vaiennetut tarjoaa kattavan tietopaketin Suomen karjalankielisten karjalaisten tilanteesta ja asemasta. Ensitöikseen Sarhimaa määrittelee kirjassaan tarkasti kaikki kielelliset, maantieteelliset ja kulttuuriset "Karjalat", sillä karjala ja karjalaiset ovat moninaisia käsitteitä (ks. Hämynen 1994, Torikka 2004). Sarhimaan kirjassa käsitellään Suomessa asuvia karjalankielisiä karjalaisia, eli karkeasti kolmea laajaa väestöryhmää Raja-Karjalan, Suomussalmen ja llomantsin karjalaisia, Vienasta ja Aunuksesta ensimmäisen ja toisen maailmansodan aikana paenneita karjalaisia sekä Neuvostoliiton hajoamisen jälkeen Suomeen muuttaneita karjalaisia. Suomessa puhuttu karjalan kieli edustaa kaikkia kolmea kielitieteessä määriteltyä karjalan kielimuotoa: varsinaiskarjalaa, johon kuuluvat viena ja eteläkarjala, sekä livviä. 
Tietokirja Vaietut ja vaiennetut on syntynyt Sarhimaan johtaman laajan ELDIA-tutkimusprojektin (European Language Diversity for All) tuloksena. Suomen karjalankieliset karjalaiset olivat tämän kansainvälisen ja monitieteisen hankkeen yhtenä tapaustutkimuksena muiden suomalais-ugrilaisten kielivähemmistöjen joukossa. ELDIA-projektin ja sen tuloksena syntyneen tietokirjan tarkoituksena on ymmärtää paitsi nykyajan karjalankielisten kielioloja Suomessa myös asettaa ne historialliseen, oikeudelliseen ja yhteiskunnalliseen kontekstiin. Sarhimaa onnistuu tässä erinomaisesti - karjalankielisten Suomen karjalaisten tilanne ja asema on kontekstualisoitu perinpohjaisesti. Tutkimusaineistona käytetään myös karjalankielisten haastatteluja ja keskusteluja erilaisissa sosiaalisen median keskusteluryhmissä. Vaikkei Vaietut ja vaiennetut ole folkloristiikan tai kansantietouden alan tutkimus, on se erittäin hyödyllinen teos myös näille aloille kontekstualisoidessaan laajasti karjalankielisen vähemmistön tilannetta kielen ja kulttuurin kannalta sekä esittäessään myös karjalankielisten omia pohdintoja nykytilasta.

Teoksessa on kahdeksan lukua, joissa kokonaisvaltaisesti valaistaan Suomessa puhutun karjalan kielen historiallisia taustoja ja muun muassa sitä, miksi karjala ei ole vakiintunut osaksi itsenäisen Suomen kielimaisemaa (luvut 2-4). ELDIA-tutkimushankkeen karjalankielisiä käsittelevää aineistoa analysoivassa luvussa viisi tarkastellaan, kuka osaa ja puhuu karjalan kieltä nyky-Suomessa ja missä sitä käytetään. Kuudennessa ja seitsemännessä luvussa kirjoittaja paneutuu niihin kielipoliittisiin keinoihin, joilla tämän uhanlaisen kielen voimaannuttaminen olisi mahdollista. Kahdeksas luku tarjoaa jämäkän yhteenvedon, jossa Sarhimaa ottaa tiukasti kantaa karjalan kielen elvyttämiseen ja kehottaa tekemään poliittisia päätöksiä yhteiskuntatuen mahdollistamiseksi unohtumatta karjalankielisen yhteisön tukemista ja aktiivisuutta oman kielen säilyttämisessä. Kirjan kokonaisrakenne on erittäin selvä, myös informatiivinen alaotsikointi ja sisäiset viitteet auttavat navigoimaan helposti kirjan sisällä.

\section{Karjalan kieli - kansallismielisen politiikan uhri}

Karjalan kieli ja kulttuuri Suomessa joutui kansallismielisen politiikan jalkoihin, ja karjalankieliset pyrittiin tietoisesti suomalaistamaan. Karjalankielisten ja suomalaisten vastakkainasettelu syveni nimenomaan kansallisuusaatteen voimistuessa. Kansallisromanttisen karelianismin seurauksena myyttistä "Karjalaa" pidettiin suomalaisuuden alkukotina ja karjalaisia suomalaisen kulttuurin ja suomalaisten myyttien säilyttäjinä venäläisestä vaikutuksesta huolimatta. Näin ollen karjalaiset edustivat suomalaisuuden ihannoitua menneisyyttä. Hyvänä esimerkkinä tästä voi pitää kalevalamittaisen runouden sekä Elias Lönnrotin Kalevalan kanonisoimista suomalaiseksi perinneaarteeksi. Samalla karjalaisilta vietiin oikeus omaan nykyisyyteen ja sen seurauksena myös tulevaisuuteen. Kuten Sarhimaa painottaa: "[k]arjalaisuus ja karjalan kieli uhrattiin tässä prosessissa suomalaisuuden hyväksi, minkä voi nähdä ensimmäiseksi niistä tietoisista ja pohjimmiltaan äärimmäisen poliittisesti motivoiduista valinnoista, jotka ovat johtaneet karjalan kielen nykytilanteeseen Suomessa" (s. 56). Suomalainen folkloristiikka, varsinkin tieteenalan alkutaipaleella, on ollut aktiivisesti vaikuttamassa yhtenäisen suomalaisuuden rakentamisessa.

Suomen itsenäistymisen jälkeen ja etenkin jatkosodan päätyttyä karjalankielisten karjalaisten assimilaatio suomenkieliseen yhteisöön vauhdittui entisestään. Tähän vaikutti myös Suomeen sijoitettujen karjalaisten vieroksunta, syrjintä ja ryssittely heidän kielensä, 
kulttuurinsa tai uskontonsa takia, mikä pakotti monet, varsinkin lapset ja nuoret, luopumaan omasta kielestään.

\section{Karjalan revitalisaatio on mahdollista, jos löytyy poliittista "tahtotilaa"}

Tällä hetkellä Suomessa on eri epävirallisten arvioiden mukaan noin 30000 karjalankielisen yhteisön jäsentä, joista noin 11000 osaa karjalaa hyvin tai erittäin hyvin (s. 114-115), päivittäin kieltä puhuu noin 5000 . Tarkat tilastot kuitenkin puuttuvat. Arviot karjalan puhujista Suomesta pohjautuvat sekä ELDIAn kyselytutkimukseen että Karjalan Kielen Seuran linjaukseen.

Sarhimaan esittämät ELDIA-hankkeen aineistoanalyysit näyttävät, että karjalaa Suomessa puhuvat ennen sotia syntyneiden vanhusten lisäksi myös nuorempi sukupolvi. Erityisen tärkeässä asemassa kielen säilymisen kannalta ovat 50-64- ja 30-49-vuotiaiden karjalan puhujaryhmät - juuri he ovat innokkaimmat oman kielen opiskelijat ja siten kielen elvyttämisen merkittävä voimavara. Sarhimaan tutkimuksesta käy ilmi myös, että Suomessa on kasvava joukko nuoria vanhempia, jotka sinnikkäästi puhuvat lapsilleen vain karjalaa. Näiden vanhempien suurimpina ongelmina on karjalankielisille lapsille suunnatun päiväkotitai kerhotoiminnan ja oman kielen kouluopetuksen ja opetusmateriaalien puute. (Ks. luku 5 kokonaisuudessaan.)

Suomessa karjalaa käytetään perheissä ja pitäjäseurojen tapaamisissa. Karjalaksi myös lauletaan, kuunnellaan musiikkia ja luetaan. Erilaiset Internet-alustat ja sosiaalinen media tarjoavat karjalankielisille sekä kotimaassa että yli rajojen mahdollisuuden verkostoitua ja käyttää omaa kieltään. Monet liittyvätkin erilaisiin verkkoryhmiin kohentaakseen kielen osaamistaan, löytääkseen päivittäistä juttuseuraa tai hakeakseen karjalankielistä aineistoa. Sarhimaan tutkimuksen mukaan tämä antaa karjalalle elintärkeän käyttöympäristön ja mahdollisuuden kielen voimaantumiseen (s. 180-184).

Suomalainen yhteiskunta on alkanut tukea karjalaa vasta 2000-luvulla. Tällä hetkellä karjalaa opetetaan Itä-Suomen yliopistossa, johon perustettiin karjalan kielen professuuri, Yle toimittaa karjalankielisiä uutisia, ja useat toimijat julkaisevat karjalankielistä kirjallisuutta. Kaikki tämä on monien järjestöjen yhteistyön ansiota, kuitenkin tärkeimpänä karjalan lobbaajana on ollut Karjalan Kielen Seura ja sen puheenjohtaja arkkipiispa Leo.

Sarhimaa ottaa vahvasti kantaa siihen, miten nyky-Suomessa voi tukea vaiennettua karjalaa. Tutkija korostaa valtion kielipoliittisen ohjelman ja oman kielilain tärkeyttä karjalan tukemiseksi ja elvyttämiseksi. Onhan Suomella suhteellisen hyviä kokemuksia saamen kielten elvyttämistoimista ja sen eteen tehdyistä poliittisista ratkaisuista, vaikka saamen puhujia on prosentuaalisesti paljon vähemmän kuin karjalan puhujia (s. 115). Riho Grünthal (2012) on Sarhimaan kanssa samoilla kannoilla:

Kielten hiipumista voidaan ehkäistä ja kehitys kääntää päinvastaiseksi, jos halutaan. Jos ei haluta, kyse on poliittisesta valinnasta, jolla on globaali kulttuurinen vaikutus. [...] Kielten katoaminen ei ole luonnonlaki. Kielten hiipumiseen, satojatuhansia puhujiakin omaavien kielten väistyminen on asenteiden, politiikan ja perimmiltään tietoisten valintojen tulosta. (Grünthal 2012, 10.) 
Anneli Sarhimaan Vaietut ja vaiennetut voi oikeasti muuttaa karjalan kielen asemaa Suomessa, jos poliitikot ja virkamiehet alkavat tehdä päätöksiä tutkittuun tietoon perustuen.

\section{Kirjallisuus}

Grünthal, Riho 2012: Suomalais-ugrilaisten vaiettu suuri kriisi. - ELO: Tuglas-seuran jäsenlehti 10(5), 8-10. [online] < https://core.ac.uk/download/pdf/14927819.pdf > [18.3.2018.]

Hämynen, Tapio 1994: Mikä Karjala? - Hämynen, Tapio (toim.), Kahden Karjalan välillä, kahden Riikin rintamalla. Joensuu: Joensuun yliopisto. 17-27.

Torikka, Marja 2004: Karjala: kieli, murre ja paikka. [online] < http://kaino.kotus.fi/www/ verkkojulkaisut/julk129/karjala sisalto.shtml > [29.3.2018.]

FT Eila Stepanova on folkloristi ja yliopistotutkija Helsingin yliopiston tutkijakollegiumissa. Hän tutkii karjalaisten pakolaisten, evakoiden ja maahanmuuttajien ja heidän jälkeläistensä menetyksen kokemuksia sekä karjalaisuuden ilmenemistä Suomessa viimeisen sadan vuoden aikana. Stepanova johtaa myös Koneen Säätiön rahoittamaa kolmivuotista hanketta "Omistajuus, kieli ja kulttuuriperintö - Kansanrunousideologiat Suomessa, Karjalan Tasavallassa ja Viron alueella". 